\title{
The Initial Model of Mathematics on Assessing Feasibility of Commercialization Higher Education Research Product in Indonesia
}

\author{
Neneng Nuryati ${ }^{1)}$, Carolina M Lasambouw ${ }^{2)}$, and Ediana Sutjiredjeki ${ }^{3)}$ \\ ${ }^{1}$ General Study Unit, Politeknik Negeri Bandung, Indonesia. \\ ${ }^{2}$ General Study Unit, Politeknik Negeri Bandung, Indonesia \\ ${ }^{3}$ Electro Department, Politeknik Negeri Bandung, Indonesia.
}

\begin{abstract}
Indonesia as a country with a total of 4,504 Universities, has good potential to produce innovative products from research activities. Research is one of the tree dharma of higher education. The results of research at university are intellectual property which has not been managed optimally until now. Since innovation is considered successful when commercialized, the results of the research have tremendous economic potential if it can be commercialized. However, not all results of an innovation are can be commercialized, although in principle the commercialization of research products is not different compared to the commercialization of ordinary products, except more difficult in practice. The study aims to determine aspects of commercialized research output in the formed of mathematical models. The mathematical model in this study is still in the development stage. The aspects for commercialization research output found in the literature are determined by several stages, including the Investigation Step, Feasibility Step, Development Step, Recognition Step, Growth Step, and Maturity Stage. Therefore, the $\mathrm{Y}$ in the Mathematical Model is commercialization, $\mathrm{X}_{1}=$ Investigation Step, $\mathrm{X}_{2}=$ Feasibility Step, $\mathrm{X}_{3}=$ Development Step, $\mathrm{X}_{4}=$ Introduction Step, $\mathrm{X}_{5}=$ Growth Stage, and $\mathrm{X}_{6}=$ Maturity Stage.
\end{abstract}

Keywords: Higher Education, Research Output, Assessment, Commercialization, Mathematical Model. 